\title{
ResearchArticle
}

\section{Aquatic bird diversity around Navaratan Sagar of Dhor, uranium mineralization site of Jahazpur Basin, Bhilwara (Rajasthan), India}

\author{
Bhagawatilal Jagetiya and Sonu Kothari
}

\begin{abstract}
SUMMARY
The radioactive mineral deposits of Bhilwara district lies at Bhunas and Jahazpur areas. In Jahazpur, Dhor and Teekhi ka Jhonpara are the main sites of uranium occurrence. Navaratan Sagar of Dhor, Jahazpur Basin, Bhilwara (Rajasthan), a water body, situated at $25^{\circ} 31^{\prime}$ North latitude and $75^{\circ} 20^{\prime}$ East Longitude. The said water body (Navaratan Sagar) is situated around uranium mineralization site of Dhor. Water bodies constitute a treasury of biodiversity. These have highly complex water and land interactive systems and are supposed to be the most fertile and productive sites. These are providing the habitat to the local and migratory bird species and playing key role in maintaining the balance in natural environmental parameters. Birds occupy a special position in an aquatic ecosystem. They not only have an aesthetic role but also occupy a very special position in the food chain. Birds, like all organisms, depend on their habitats for food, water, shelter and opportunities to breed and raise young. Climate change may alter animal behaviour, population size, species distributions, plant/animal communities as well as ecosystem function and stability. Biodiversity differs from place to place so because environmental conditions of the area as well as the range of tolerance of the species can occur in that area. Environmental changes due to natural metal mineralization also exert the selective pressure on biodiversity. Hence, every mineralization site has its specific biodiversity which may be indicator of that mineralization. There is very little work on aquatic bird diversity around uranium mineralization areas in India, in general and Navaratan Sagar of Dhor, Jahazpur Basin of Rajasthan, in particular. The important aim of this work was to evaluate the general bird diversity and explore indicator bird species of uranium mineralization. The all sighted birds around Navatan Sagar of Dhor, uranium mineralization site were common and fresh water resident. A total of 26 bird species belonging to 19 families were encountered during the study period. Among these, 21 species were resident, and 5 species were winter migrants. No indicator bird species for uranium mineralization was observed. Water samples from different sites were also collected to record physico-chemical parameters. The water of Navaratan Sagar has good amount of dissolved oxygen reflects that it is an undisturbed fresh water ecosystem. Diminution in water retention in this water body in summer has affected the bird diversity in the study area. It is concluded that Navaratan Sagar may be a good habitat to local and migratory birds.
\end{abstract}

MEMBERS OF THE RESEARCH FORUM

Author to be contacted :

Bhagawatilal Jagetiya, Phytotechnology Research Laboratory, Department of Botany, M.L.V. Government College, Bhilwara (Rajasthan) India Email : bljagetiya@yahoo.com

Address of the Co-authors:

Sonu Kothari, Phytotechnology Research Laboratory, Department of Botany, M.L.V. Government College, Bhilwara (Rajasthan) India
Key Words : Water body, Uranium mineralization, Navaratan Sagar, Bird diversity

How to cite this article : Jagetiya, Bhagawatilal and Kothari, Sonu (2018). Aquatic bird diversity around Navaratan Sagar of Dhor, uranium mineralization site of Jahazpur Basin, Bhilwara (Rajasthan), India. Internat. J. Plant Sci., 13 (2): 213-222, DOI: 10.15740/HAS/ IJPS/13.2/213-222, Copyright@ 2018: Hind Agri-Horticultural Society. 